\title{
Performance Characteristics of Lithium Titanate Doped Zirconium as Anode Material of Lithium Ion Battery and Its Potential for Cycle Recovery
}

\author{
Slamet Priyono ${ }^{1}$, Ahmad Sohib ${ }^{1}$, Wahyu Bambang Widayatno ${ }^{1 *}$, Ilma Nuroniah ${ }^{1}$, Achmad Subhan $^{1}$, Chairul Hudaya ${ }^{2}$ and \\ Bambang Prihandoko ${ }^{1}$
}

${ }^{1}$ Research Centre for Physics, Indonesian Institute of Sciences (LIPI) Kawasan Puspiptek Serpong Gd. 442 Tangerang

Selatan, Banten 15314, Indonesia

${ }^{2}$ Department Electrical Engineering, Universitas Indonesia, Depok, West Java 16424, Indonesia

\begin{abstract}
Lithium titanate or $\left(\mathrm{Li}_{4} \mathrm{Ti}_{5} \mathrm{O}_{12}\right)$ is one of potential materials applied as anode material for energy storage device. The material, however, has poor electrochemical properties. This study is aimed to study Zrdoped $\mathrm{Li}_{4} \mathrm{Ti}_{5} \mathrm{O}_{12}$ properties and electrochemical performance in a full cell. In this work, a facile solid state reaction is employed to prepare $\mathrm{Li}_{4} \mathrm{Ti}_{5-\mathrm{x}} \mathrm{O}_{12} \mathrm{Zr}_{\mathrm{x}}(\mathrm{x}=0,0.025,0.05$, and 0.075). Starting materials were stoichiometrically calculated and handily mixed for an hour, followed by calcination at $800^{\circ} \mathrm{C}$ for three hours. The XRD pattern reveals that the shipments to the higher angel of the highest peak are observed and indicate successful substitution process. The half-cell ( $\mathrm{Li}$ metal/ $/ \mathrm{Li}_{4} \mathrm{Ti}_{4.95} \mathrm{O}_{12} \mathrm{Zr}_{0.05}$ ) provides the highest conductivity value of the assembled cells, $0.15 \mathrm{mS} \mathrm{cm}^{-1}$. Cyclic Voltammetry measurement exhibits that the reduction peak of each half-cell is enhanced as an increasing amount of zirconium. The Charge-Discharge test also confirm that the highest capacity of the cells, $135.0 \mathrm{mAhg}^{-1}$, is achieved by the cell based $\mathrm{Li}_{4} \mathrm{Ti}_{4.95} \mathrm{O}_{12} \mathrm{Zr}_{\text {o.05 }}$. Full cell performance present that $\mathrm{Li}_{4} \mathrm{Ti}_{4.95} \mathrm{O}_{12} \mathrm{Zr}_{0.05}$ own higher capacity at various C-rates. Moreover, the specific capacitance of full cell based $\mathrm{Li}_{4} \mathrm{Ti}_{4.95} \mathrm{O}_{12} \mathrm{Zr}_{\text {o.o5 }}$ can sustain $82 \%$ after $100^{\text {th }}$ cycle at $0.5 \mathrm{C}$, higher than that of $\mathrm{Li}_{4} \mathrm{Ti}_{5} \mathrm{O}_{12}$ (22.4\%). In addition, full cell performance also exhibits a potential for recovery cycle as shown in $90^{\text {th }}$ cycle.
\end{abstract}

Keywords: Zi-doped LTO; electrochemical properties; lithium ion battery

\section{INTRODUCTION}

The increasing number of air pollutions from carbon dioxide $\left(\mathrm{CO}_{2}\right)$ in our environment becomes a great challenge for researchers to solve through energy storage devices. One of the sectors that highly contributed to air pollution is those produced from fossil fuel combustions such as industrial and transportation sectors. In order to decline these hazardous pollutions, some countries began to develop and implement hybrid electric vehicle (HEV), the energy source of which was electrical energy stored in Lithium ion battery (LIB), a type of lighter battery, larger capacity, and longer cycle (Linden and Reddy, 2002). However, the utilization of LIB is extremely limited by several factors including its production cost, safety, and performances, especially for transportation. In addition, LIB as a crucial component for HEV must possess a good gravimetric (Wh/g) and volumetric (Wh/L) energy density as well (Park et. al., 2018; Lu et al., 2018). Therefore, LIB needs to develop in modifying the composed materials, particularly materials of three main-LIB components, namely cathode, anode, and electrolyte (Linden \& Reddy, 2002).

Lithium titanium oxide $\left(\mathrm{Li}_{4} \mathrm{Ti}_{5} \mathrm{O}_{12}\right)$ commonly abbreviated as LTO is considered as promising anode material of LIB due to the advantages it belongs. This material was first introduced by Freg et al. (1994) and applied as anode material of LIB in 1994 and it is classified into $\mathrm{Li}_{1+\mathrm{x}} \mathrm{Ti}_{2-\mathrm{x}} \mathrm{O}_{4}$ $(0 \leqslant x \leqslant 1 / 3)$ group featured spinel structure (Ozen et. al., 2016; Ferg et al., 1994). Its cubic structure is able to stabilize its volume change during charging-discharging process and

* Corresponding author's e-mail: wahyuwb@gmail.com 
it exhibits theoretical capacity of approximately $175 \mathrm{mAhg}^{-1}$ (Wang et. al., 2014; Rutkowska et. al., 2017; An et. al., 2018; Gockeln et. al., 2018). LTO also owns a compatible potential voltage, 1.55 volt, at which solid electrolyte interface (SEI) is stably formed in the electrode (Kim \& Yoon, 2013; Sandhya et al., 2014). Therefore, LTO is nominated as material to replace commercial anode material, e.g. graphite, ascribed as incompatible for high power LIBs, which HEV is necessary to possess (Subhan et al., 2019). Besides its advantages, LTO, however, has characteristics that need to be reinforced, namely electrical conductivity and diffusion coefficient which play an essential role in improving the performance of LTO in batteries (Fu et al., 2016).

Several approaches, like structure modification and diminishing particle size, have already been carried out in order to improve its properties during the past decade. Some researchers tried to modify the structure of LTO by substituting metal and non-metal ions to various sites of LTO structure. Metal ions such as $\mathrm{Cu}^{3+}, \mathrm{Fe}^{3+}, \mathrm{Mg}^{2+}, \mathrm{Ca}^{3+}$, $\mathrm{Nb}^{5+} \mathrm{Br}^{-}, \mathrm{F}^{-}$and $\mathrm{Al}^{3+}$ were introduced at $\mathrm{Li}, \mathrm{Ti}$, and $\mathrm{O}$ site in LTO structure and might cause more conductive (Chen et. al., 2001; Qi et. al., 2009; Cai et. al., 2012; Tian et. al., 2012; Wang et. al., 2013; Hernandez-Carrillo et. al., 2018; Liang et. al., 2018; Sohib et al., 2020). Another one is Zirconium $\left(\mathrm{Zr}^{4+}\right)$, which is considered as one of metal ions enabling to substitute at $\mathrm{Ti}$ site and allowed to increase the diffusion coefficient and submicron particle sizes. Wang et al. (2014) once prepared Zr-doped LTO with $5 \mathrm{wt} \%$ phenolic resin and $\mathrm{ZrO}_{2}$ as $\mathrm{Zr}^{4+}$ source via solid state reaction and wet milling. Other zirconium sources, e.g. $\mathrm{Zr}\left(\mathrm{NO}_{3}\right)$ and $\mathrm{Zr}$-n-butoxide have been chosen as $\mathrm{Zr}^{4+}$ precursors to achieve excellent cycle stability of full cell based LTO (Gu et. al., 2012; Hou et al., 2019). As far as we know that Zirconium silicate $\left(\mathrm{ZrSiO}_{4}\right)$ is rare to study as $\mathrm{Zr}^{4+}$-dopant source for LTO, even though it contains silicate which binds more electron suggesting high conductivity (Chen et al., 2018). This zirconium source is also considered as abundant material in nature suggesting low-cost LTO. It is also seldom to analyze in full cell performance, especially for Zr-doped LTO in order to investigate its practical battery application.

$\mathrm{Zr}$-doped LTO via a facile solid state reaction method was successfully synthesized at various dopant contain. However, the low $\mathrm{Zr}$ concentration of Zr-doped LTO and its application in full cell battery have rarely been reported. In this article, $\mathrm{Zr}$-doped LTO with low $\mathrm{Zr}$ concentration $\left(\mathrm{Li}_{4} \mathrm{Ti}_{5-}\right.$ ${ }_{\mathrm{x}} \mathrm{O}_{12} \mathrm{Zr}_{\mathrm{x}}$, where $\mathrm{x}=0,0.025,0.05$, and 0.075) were synthesized via facile solid-state reaction. Furthermore, Zrdoped LTO was applied as anode material for full cell battery based $\mathrm{LiFePO}_{4}$-Cathode. The electrochemical performances of half-cell (Zr-doped LTO vs Li metal) and full cell battery (Zr-doped LTO vs $\mathrm{LiFePO}_{4}$ ) including cyclic voltammetry $(\mathrm{CV})$ and its capacitance stability are provided.

\section{MATERIALS AND METHOD}

\section{A. Synthesis $\mathrm{Li}_{4} \mathrm{Ti}_{5^{-}} \mathrm{O}_{12} \mathrm{Zr} r_{x}$}

A facile solid-state reaction is employed to synthesize $\mathrm{Li}_{4} \mathrm{Ti}_{5-}$ ${ }_{\mathrm{x}} \mathrm{O}_{12} \mathrm{Zr}_{\mathrm{x}}$ (initial amount of $\mathrm{x}=0,0.025,0.05$, and 0.075 ) at $\mathrm{mol} / \mathrm{mol}$. Lithium carbonate (Merck, purity >98\%) and titanium oxide in (Merck, Anatase purity >97\%) were used for lithium and titanium source. For $\mathrm{Zr}$ source, zirconium silicate $\left(\mathrm{ZrSiO}_{4}\right)$ taken from zirconium sands in our laboratory was used. The zirconium sands were cleaned by water and milled via high energy milling in order to obtain fine powders.

Initially, the starting materials were continuously mixed via simple handy mixing for an hour using a mortar. The powders then were calcined at $800^{\circ} \mathrm{C}$ for three hours in the air environment and analysed by some characterizations. The sample of $\mathrm{Li}_{4} \mathrm{Ti}_{5-\mathrm{x}} \mathrm{O}_{12} \mathrm{Zr}_{\mathrm{x}}(\mathrm{x}=0,0.025,0.05$, and 0.075) was labelled by LTO, LTOZ 0.025, LTOZ 0.05, and LTOZ 0.075

To investigate the electrochemical performance of doped LTO, the acquired powders were assembled into a half cell as well as full cell. The preparation of the working electrode was conducted by mixing the active materials (pristine LTO or doped LTO), a binder (polyvinilydene fluoride or PVDF), and carbon black (Super-P) with ratio 85:10:5 (w/w) respectively in a solvent, N,N Dimethyl Acetamide (DMAC) for an hour at $70^{\circ} \mathrm{C}(250 \mathrm{rpm})$. This solvent was chosen due to its high stability, suggesting to avoid reacting with active materials (Wang et al., 2017). Then, the obtained slurry was cast on copper foil using Automatic film coater machine. Subsequently, the resulted film was shaped into a disk with $16 \mathrm{~mm}$ in diameter. The disks were dropped by $1 \mathrm{M} \mathrm{LiPF}_{6}$ in EC:EMC (1:6 v/v) as electrolyte and sandwiched with 
Celgrad (porous separator) and lithium metallic as a counter electrode for half-cell coin type CR2032. For further investigation, full cell batteries are also assembled using commercial $\mathrm{LiFePO}_{4}$ (LFP) as a cathode material and dropped by the same electrolyte. The full cell of LTO and LTOZ 0.05 are named as LFP// LTO and LFP//LTOZ 0.05.

\section{B. Characterisation and Measurement}

The calcined powders were examined by an X-Ray Diffraction ( $\mathrm{CuKa}$ / wave length $1.541862 \AA$ ) in 2-theta range 10 degree to 90 degree at room temperature in order to probe their formed phase since the restructuring process or calcination. The powders are morphologically captured by Field Emission Scanning Electron Microscope (FESEM, JEOL 4610 Japan) featured by Energy Diffraction X-Ray (EDX) at 20000 magnification, $10.0 \mathrm{kV}$. The coin cells were evaluated by Wontech 3000 WBCS via cyclic voltammetry (CV) with various scan rate $0.1-0.55 \mathrm{mV} / \mathrm{s}$ over voltage 0.5 volt to 2.5 volt and charge-discharge (CD) test with current rate $0.1 \mathrm{C}$ at room temperature. The ionic conductivity properties of the cells were measured by Electrochemical Impedance Spectroscopy (HIOKI 5322-50 LCR HiTESTER) with frequency $0.1 \mathrm{~Hz}-50 \mathrm{kHz}$. The full cells, LFP//LTO and LFP//LTOZ 0.05 were also observed through CV at 0.1 $\mathrm{mVs}^{-1}$ and $\mathrm{CD}$ at various C-rate at the same instrument.

\section{RESULT AND DISCUSSION}

\section{A. X-Ray Diffraction Analysis}

After the synthesis process, the obtained powder of LTO and Zr-doped LTO are then carried out to be analysed using XRD. The results of XRD measurement are displayed in Figure 1. Each sample shows a spinel-LTO pattern with Fd3m space groups, the peaks of which are approximately detected $2 \Theta$ value at $18^{\circ}, 37^{\circ}, 43^{\circ}, 49^{\circ}, 5^{\circ}, 63^{\circ}, 66^{\circ}, 75^{\circ}, 76^{\circ}$, and $79^{\circ}$ (PDF Card No.: 0o-049-0207). This indicates that doping Ti site by $\mathrm{Zr}^{+4}$ does not vary the structure of LTO. The peak however appears at 2-theta angles around $27^{\circ}$, $27.5^{\circ}$, and $36^{\circ}$ which is ascribed as other titanium oxides referring to Rutile (PDF Card No.: 01-086-0148) and $\mathrm{LiTiO}_{2}$ (PDF Card No.: 04-002-8221).
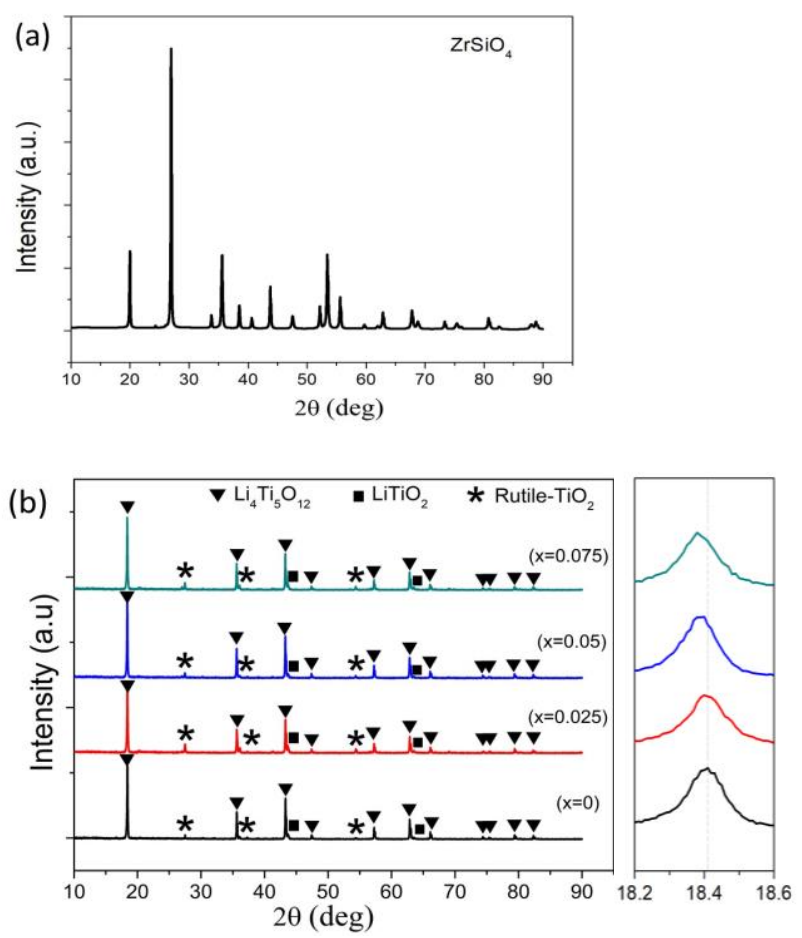

Figure 1. Diffraction pattern of (a) $\mathrm{ZrSiO}_{4}$ and (b) various LTO, LTOZ 0.025, LTOZ 0.05, and LTOZ 0.075 featured magnified peak at $18.2^{\circ}-18.6^{\circ}$

The impurities are thought from starting materials that are not evenly mixed and reacted well. As the highest-intensity peak of LTO, namely at $18.4^{\circ}$ referred to (111) plane is magnitude, each sample of Zr-doped LTO encounters a shift to the higher angel. These shifts are supposed to be an indication that the $\mathrm{Zr}^{4+}$ successfully take place the titanium site in the LTO structure. The other information namely contents and lattice parameters of the LTO structure can also be calculated by Bragg's equation as shown in Table 1. It can be seen that the lattice parameters of the Zr-doped LTO structure becomes larger than that of LTO as the increased $\mathrm{Zr}^{4+}$ content. It may be caused by metal ions $\mathrm{Zr}^{4+}$ that occupy Ti sites with larger ionic radius, around 8/7 times the radius of $\mathrm{Ti}$ ion (Wang et al., 2014). The larger lattice parameters can generate the distance between atoms in the LTO structure enhanced, suggesting wide diffusion pathway of $\mathrm{Li}$ ion. This will allow $\mathrm{Li}$ ions to diffuse from one site to another and provides a high conductivity. 

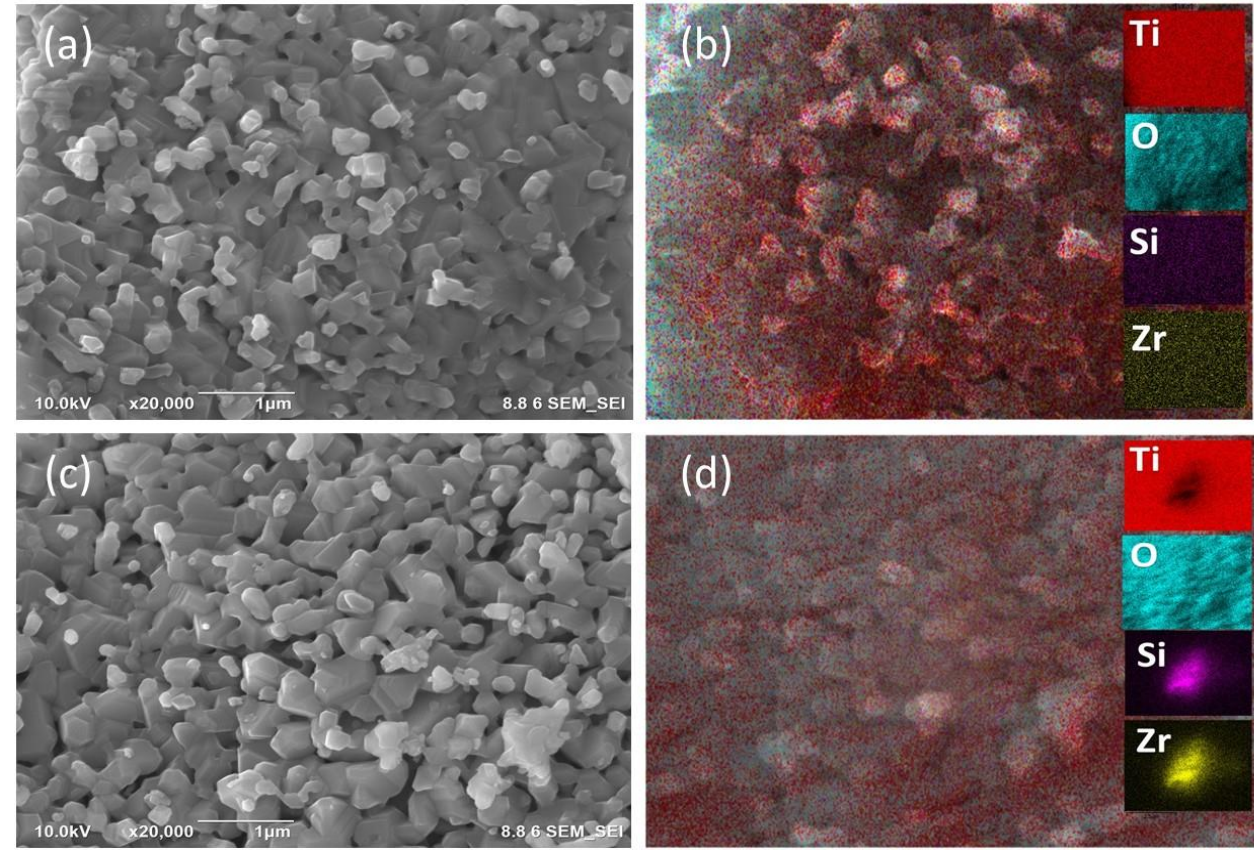

Figure 2. Morphological capture featured with EDX of (a-b) pristine LTO and (c-d) LTOZ 0.05 at 20000 magnification featured by element distribution

\section{B. Morphology Analysis}

Figure 2 displays the morphological analysis of pristine LTO and LTOZ 0.05 sample to investigate the particle and element distribution. As shown in Figure 2(a-c), it is obviously exhibited that both of samples have similar particle size approximately 200-400 nm. However, Sample LTOZ 0.05 appears more porous than that of LTO. The porous electrode materials enable more active materials which intake and react with electrolyte so that it could enhance the capacity and have better performance. In addition, Figure 2(b-d) show the element distribution on LTO and LTOZ 0.05 morphology which were detected by EDX measurement. The distributions of LTO and LTOZ 0.05 significantly show no differences. The undoped LTO and LTOZ 0.05 reveal that Titanium and Oxygen are well distributed.

\section{Electrochemical Investigation}

The performances of LTO-based half cells were initially investigated by electrochemical characterization in Figure 3. Figure 3(a) reveals the results of cyclic voltammetry from sample LTO, LTOZ 0.025, LTOZ 0.05, and LTOZ 0.075 at $0.1 \mathrm{mVs}^{-1}$ in voltage range of $0.5-2.5$ volt. The oxidation and reduction peaks of the electrochemical reaction process are clearly observed in each cell and located approximately at 1.25 volt for oxidation peak and at 1.75 volt for reduction peak, relatively close to the working voltage of the LTO, 1.55 volt (Rho \& Kanamura, 2004; Sandhya et. al., 2014; Sun et al., 2014). As it is well known in previous articles, the pairs of these peaks are considered as an indication in which a reversible system take place as well (Wang, 2001). This phenomenon can be evidence that the $\mathrm{Zr}^{4+}$ substitution on titanium sites does not affect the presence of the oxidation and reduction reaction in the battery cell. Besides, the existence of other redox peaks referred to the impurities detected in diffraction pattern (Rutile- $\mathrm{TiO}_{2}$ and $\mathrm{LiTiO}_{2}$ ) does not appear. It means that the amount of impurities contained in each sample is not quite much. As further investigation regarding to the effect of dopant $\mathrm{Zr}^{4+}$, it is obviously exhibited that doping $\mathrm{Zr}^{4+}$ at Ti site in LTO structure can increase the current response as elevated content of $\mathrm{Zr}^{4+}$ up to $5 \%$, while the response started declining at $7.5 \%$. This may be due to the excessive of $\mathrm{Zr}^{4+}$ content in the structure of LTO. As comparison, in this study, the current response of the cell based LTOZ 0.05 reach 6.9 $\mathrm{mA}$ at a quite slow scan rate, $0.1 \mathrm{mVs}^{-1}$ and appears higher than that of the cell based LTOZ 0.05 reported in some articles (Li et. al., 2009; Gu et al., 2012). This phenomenon may be explained through the anode material contained 
silicon, which theoretically has quite high specific capacity of increasing current response (Kim, Lee \& Sun, 2014).

The following investigation is to understand further kinetic properties of the LTO and LTOZ 0.05 half-cells measured by $\mathrm{CV}$ test at various scan rates, $0.1 \mathrm{mVs}^{-1}$ to 0.55 $\mathrm{mVs}^{-1}$ as demonstrated in Figure 3(b) and (c). Current response of each cells from this test proportionally rises as increasing scan rate, which indicates that the $\mathrm{Li}^{+}$inside of the cells transport and moved rapidly. These properties can contribute to excellent reversibility and cycle stability (Yi et al., 2015). The other properties which might be explored from this electrochemical characterization was diffusion coefficient using the following equation (Hou et al., 2019),

$$
i_{p}=2.69 \times 10^{5} A^{3 / 2} D^{1 / 2} C_{L i} v^{1 / 2}
$$

Where $i_{p}$ and $v$ represent current peak (A) and scan rate applied in the test $\left(\mathrm{Vs}^{-1}\right)$. $\mathrm{n}, \mathrm{C}_{\mathrm{Li}+}, \mathrm{A}$, and $\mathrm{D}$ respectively mean mount of charge in active material (commonly $n=1$ for LTO), $\mathrm{Li}^{+}$concentration in the electrode $(\mathrm{mol} \mathrm{cm}-3)$, area of electrode $\left(\mathrm{cm}^{2}\right)$, and diffusion coefficient $\left(\mathrm{cm} \mathrm{s}^{-1}\right)$. By determining the slope of linear graph between current peak vs the root of scan rate as displayed in Figure 2(d), the coefficient can be calculated as listed in Table 2. It obviously reveals that substituted $\mathrm{Zr}^{4+}$ into Ti site of LTO structure can enhance the coefficient diffusion. Higher coefficient diffusion can be caused by doping $\mathrm{Zr}$ suggesting to enlarge the diffusion pathway of lithim ion, $\mathrm{Li}^{+}$, therefore, enable moves to another site easily. The storage capacity performance of the half-cell based on the LTO and Zr-doped LTO were examined by CD test at current rate of $0.1 \mathrm{C}$ and it is shown in Figure 2(e). All the cells based LTO and Zrdoped LTO mostly exhibit a plateau voltage at $1.60-1.54$ volts for charge and discharge voltages. This CD test also represent that the initial obtained specific capacitance of LTO, LTOZ 0.025, LTOZ 0.05, and LTOZ 0.075 samples is respectively stated $128.7 \mathrm{mAhg}^{-1}, 123.7 \mathrm{mAhg}^{-1}$, 135.0 $\mathrm{mAhg}^{-1}$, and $120.0 \mathrm{mAhg}^{-1}$. It is distinctly observed that LTOZ 0.05 is the best composition demonstrating higher specific capacity which is confirmed by CV and EIS testing as well. Consequently, the sample LTOZ 0.05 is selected as anode in full-cell battery in this study.
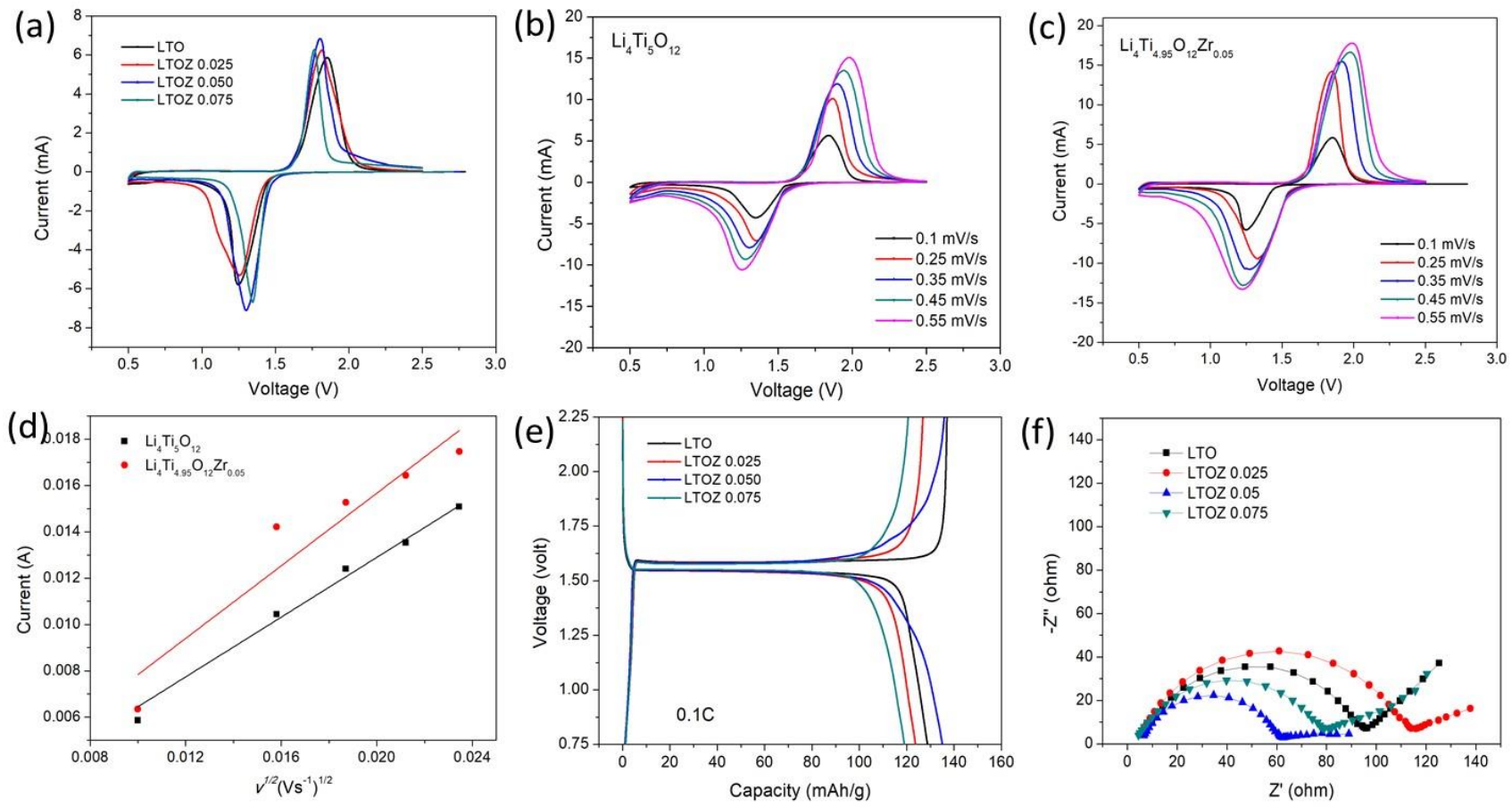

Figure 3. Electrochemical characterization: (a) Cyclic voltammetry profile of LTOZ (x = 0, 0.025, 0.05, and 0.075) at 0.1 mVs-1, (b) LTO and (c) LTOZ ( $\mathrm{x}=0.05$ ) at various scan rate $0.1-0.55 \mathrm{mVs}-1$, (d) Current peak vs the root of scan rate, (e) Charge-Discharge and (f) Nyquist plot of cells based LTO and LTOZ 

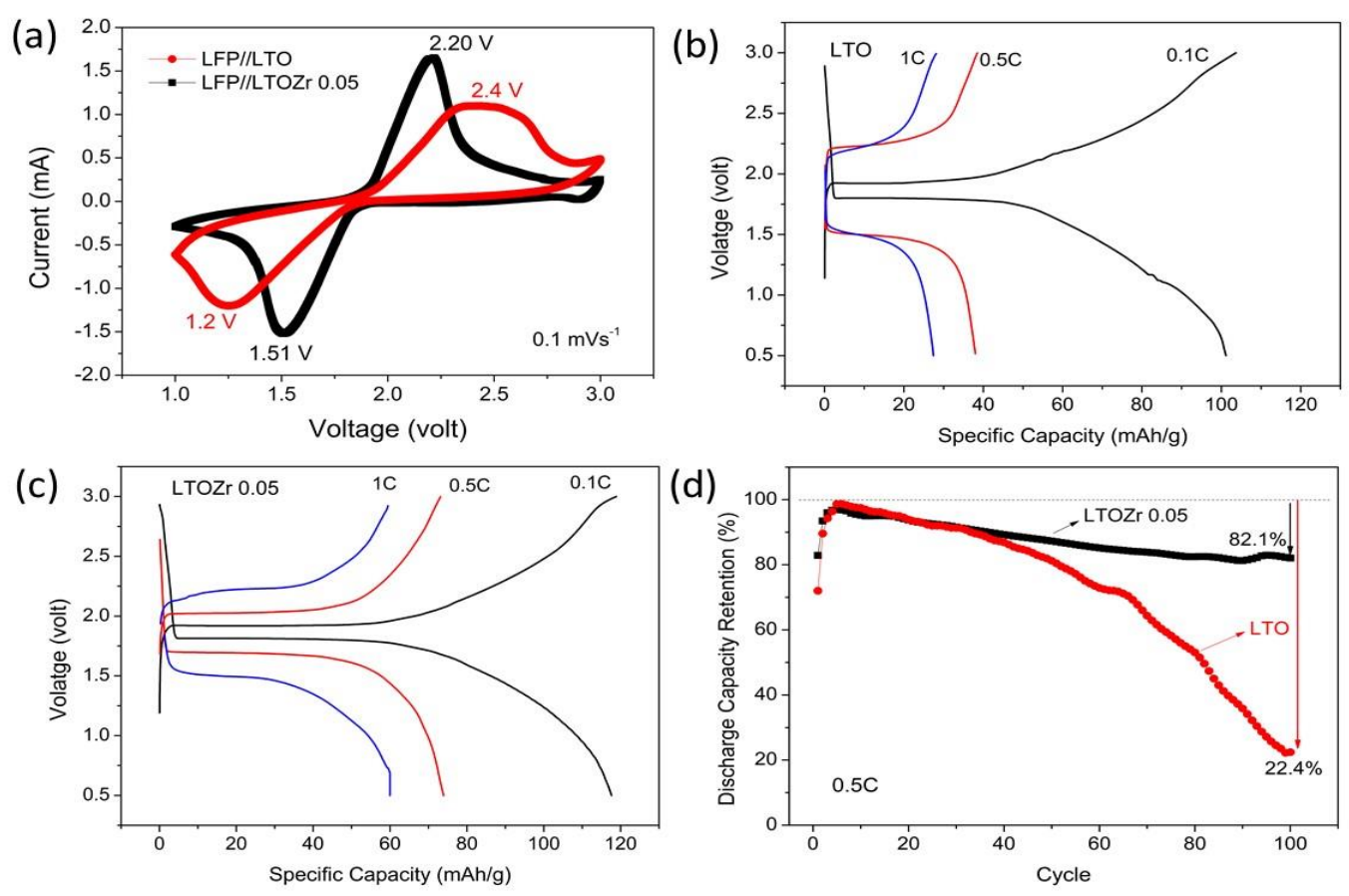

Figure 4. The electrochemical profile of the full cell: (a) cyclic voltammogram, (b-c) Chargecharge behaviour, and (d) retention performance of full cell based LTO and LTOZ 0.05 anod

Electrochemical performance of full-cell battery is conducted in order to observe its practical application through CV and CD test. Figure 4(a) displays the cyclic voltammetry profile of the full cell at scan rate $0.1 \mathrm{mVs}^{-1}$ in range 1-3 volt. Both of the full cell demonstrate couple of redox peaks, suggesting reversible system (Linden \& Reddy, 2002). In addition, It might be seen that LFP//LTOZ 0.05 own the higher and sharper redox peaks than those of LFP// LTO. Furthermore, it is distinctly exhibited that redox peaks of LFP//LTOZ 0.05 is closer than that of LFP//LTO which means that LFP//LTOZ 0.05 has smaller voltage difference (o.69 volt) than that of LFP//LTO (1.2 volt). Theoretically, the voltage difference is defined by polarization degree inside the cell (Wang et al., 2014). Figure 4(b) and (c) display the Charge-Discharge behaviour of LFP//LTO cell and LFP//LTOZ 0.05 cell at various C-rates of $0.1 \mathrm{C}, 0.5 \mathrm{C}$, and $1 \mathrm{C}$. The capacity of the full cells is respectively represented by $117.75 \mathrm{mAhg}^{-1}, 73.87 \mathrm{mAhg}^{-1}, 59.89 \mathrm{mAhg}^{-1}$ for LFP//LTOZ 0.05 and 100.1 $\mathrm{mAhg}^{-1}, 38.02 \mathrm{mAhg}^{-1}, 27.28$ $\mathrm{mAhg}^{-1}$ for $\mathrm{LFP} / / \mathrm{LTO}$ at $0.1 \mathrm{C}, 0.5 \mathrm{C}$, and ${ }^{1 \mathrm{C}}$. From this measurement, $\mathrm{Zr}^{4+}$ substitution at $\mathrm{Ti}$ site may stabilize the capacity at various C-rate. Cycle investigation was also tested using $\mathrm{CD}$ measurement to observe the stability retention at $0.5 \mathrm{C}$ for 100 cycles, as shown in Figure $4(\mathrm{~d})$. At the beginning cycle, the capacitances of both LFP// LTO and LFP//LTOZ 0.05 incline due to the fact that the electrolyte penetration anode and cathode materials is incomplete (Zhang et al., 2012). It is noticeably seen that the discharge capacity of LPF//LTO cell is dropped starting at around $30^{\text {th }}$ cycle more drastically than that of LFP//LTOZ 0.05. It may be explained that modifying structure of LTO via ion-metal introduction may shift the low unoccupied molecular orbital (LUMO) and the high occupied molecular orbital (HOMO) level (Bandaru et. al., 2015; Jin et al., 2016). This shifting level relates to solid electrode interface (SEI) layer formed during charging-discharging mechanism on the surface of electrodes. The layer can resist the ion mobility and enable to fade its capacity (Zhang et al., 2011). The stable capacitance may be affected by the longer path of $\mathrm{Li}^{+}$ mobility suggesting sophisticated diffusion shown in Figure 3(d) and confirmed by XRD measurement (Lu et al., 2017). The cell based LPF//LTOZ 0.05 sustains up to $82 \%$, while the cell based LTO can only sustain $22.4 \%$ after 100 cycles.

\section{CONCLUSION}

Zr-doped LTO at low concentration of zirconium through solid state reaction was successfully carried out. The XRD 
pattern confirms that ion $\mathrm{Zr}^{4+}$ was succeeded to substitute into $\mathrm{Ti}$ site and it does not change the spinel structure of LTO, even some impurities, rutile $\mathrm{TiO}_{2}$ and $\mathrm{LiTiO}_{2}$, still appear in the acquired powders. The cell with LTOZ 0.05 provides the highest conductivity value of the assembled cells. In addition, $\mathrm{CV}$ measurement exhibits that the current peak of the cells is enhanced as increasing amount of zirconium. The $\mathrm{CD}$ test also informs that the highest capacity of the cells, $135.0 \mathrm{mAh} / \mathrm{g}$, is achieved by the cell based LTOZ 0.05. Full cell LFP//LTOZ 0.05 has a sharper current peak and low polarization degree than full cell LFP//LTO. LFP//LTOZ 0.05 shows excellent cycle stability proven by $82 \%$ capacity sustain after 100 cycles. Therefore, $\mathrm{ZrSiO}_{4}$ is a promising dopant source to modify structure in order to address the high synthesis cost of LTO for lithium battery application.

\section{ACKNOWLEDGEMENT}

This research is partially funded by Ministry of Research, Technology, and Higher Education of Republik Indonesia under Insentif Riset Sistem Inovasi Nasional (INSINAS) scheme (contract number 30/INS1/PPK/E4/2019) and partially supported by Indonesia Toray Science Foundation $26^{\text {th }}$ Research Grant (FY 2019). The authors acknowledge Research Center for Physics, Indonesian Institute of Sciences (LIPI) for providing experimental and characterization supports.

\section{REFERENCES}

An, D, Shen, L, Lei, D, Wang, L, Ye, H, Li, B, Kang, F \& He, YB 2018, 'An ultrathin and continuous Li4Ti5O12 coated carbon nanofiber interlayer for high rate lithium sulfur battery', Journal of Energy Chemistry, vol. 31, pp. 19-26. doi: 10.1016/j.jechem.2018.05.002.

Bandaru, PR, Yamada, H, Narayanan, R \& Hoefer, M 2015, 'Charge transfer and storage in nanostructures', Materials Science \& Engineering R: Reports, vol. 96, pp. 1-69. doi: 10.1016/j.mser.2015.06.001.

Cai, R, Jiang, S, Yu, X, Zhao, B, Wang, H \& Shao, Z 2012, 'A novel method to enhance rate performance of an Al-doped Li4Ti5O12 electrode by post-synthesis treatment in liquid formaldehyde at room temperature', Journal of Materials Chemistry, vol. 22, no. 16, pp. 8013-8021. doi: 10.1039/c2jm15731d.

Chen, CH, Vaughey, JT, Jansen, AN, Dees, DW, Kahaian, AJ, Goacher, T \& Thackeray, MM 2001, 'Studies of Mgsubstituted Li4-xMg x Ti5O12 spinel electrodes ( $\leq x \leq 1)$ for lithium batteries', Journal of the Electrochemical Society, vol. 148, no. 1, p. A102.

Chen, M, Li, B, Liu, X, Zhou, L, Yao, L, Zai, J, Qian, X \& Yu, $\mathrm{X}$ 2018, 'Boron-doped porous Si anode materials with high initial coulombic efficiency and long cycling stability', Journal of Materials Chemistry A, vol. 6, no. 7, pp. 3022-3027. doi: 10.1039/c7ta10153h.

Ferg, E, Gummow, RJ \& Kock, A De 1994, 'Spinel anodes for lithium-ion batteries', Journal of the Electrochemical
Society, vol. 141, no. 11, pp. 9-12.

Fu, C, Zhang, L, Peng, J, Wang, H \& Yan, H 2016, 'Synthesis of Li4Ti5O 12-reduced graphene oxide composite and its application for hybrid supercapacitors', Ionics, vol. 22, no. 10, pp. 1829-1836. doi: 10.1007/s11581-016-1726-x.

Gockeln, M, Pokhrel, S, Meierhofer, F, Glenneberg, J, Schowalter, M, Rosenauer, A, Fritsching, U, Busse, M, Mädler, L \& Kun, R 2018, 'Fabrication and performance of Li4Ti5O12/C Li-ion battery electrodes using combined double flame spray pyrolysis and pressure-based lamination technique', Journal of Power Sources, vol. 374, pp. 97-106. doi: 10.1016/j.jpowsour.2017.11.016.

$\mathrm{Gu}, \mathrm{F}$, Chen, G \& Wang, $\mathrm{Z}$ 2012, 'Synthesis and electrochemical performances of Li4Ti4.95 Zr $0.05 \mathrm{O}$ 12/C as anode material for lithium-ion batteries', Journal of Solid State Electrochemistry, vol. 16, no. 1, pp. 375-382. doi: 10.1007/s10008-011-1326-7.

Hernández-Carrillo, RA, Ramos-Sánchez, G, GuzmánGonzález, G, García-Gomez, NA, González, I \& SanchezCervantes, EM 2018, 'Synthesis and characterization of iron-doped Li4Ti5O12 microspheres as anode for lithiumion batteries', Journal of Alloys and Compounds, vol. 735, pp. 1871-1877. doi: 10.1016/j.jallcom.2017.11.218.

Hou, L, Qin, X, Gao, X, Guo, T, Li, X \& Li, J 2019, 'Zr-doped Li4Ti5O12 anode materials with high specific capacity for lithium-ion batteries', Journal of Alloys and Compounds, vol. 774, pp. 38-45. doi: 10.1016/j.jallcom.2018.09.364. 
An, SJ, Li, J, Daniel, C, Mohanty, D, Nagpure, S \& Wood III, DL 2016, 'The state of understanding of the lithium-ionbattery graphite solid electrolyte interphase (SEI) and its relationship to formation cycling', Carbon, vol. 105, pp. 52-76. doi: 10.1016/j.carbon.2016.04.008.

Kim, H, Lee, E \& Sun, Y 2014, 'Recent advances in the Sibased nanocomposite materials as high capacity anode materials for lithium ion batteries', Materials Today, vol. 17, no. 6, pp. 285-297. doi: 10.1016/j.mattod.2014.05.003. Kim, JH \& Yoon, JR 2013, 'Preparation and characterization of Li4Ti5O12 synthesized using hydrogen titanate nanowire for hybrid supercapacitor', Journal of Advanced Ceramics, vol. 2, no. 3, pp. 285-290. doi: 10.1007/s40145013-0073-X.

Li, X, Qu, M \& Yu, Z 2009, 'Structural and electrochemical performances of Li4Ti5-xZrxO12 as anode material for lithium-ion batteries', Journal of Alloys and Compounds, vol. 487, pp. 12-17. doi: 10.1016/j.jallcom.2009.07.176.

Deng, H, Liang, W, Nie, D, Wang, J, Gao, X, Tang, S, Liu, C \& Cao, YC 2018, 'High rate performance of Ca-doped Li4Ti5O12 anode nanomaterial for the lithium-ion batteries', Journal of Nanomaterials, 2018, pp. 1-6. doi: 10.1155/2018/7074824

Linden, D \& Reddy, TB 2002, Handbook of Batteries, 3rd edn, McGraw-Hill Companies, New York, US.

Lu, Chengxing, Xin Wang, Xin Zhang, Huifen Peng, Yongguang Zhang, Gongkai Wang, Zhenkun Wang, Guanlong Cao, Nurzhan Umirov \& Zhumabay Bakenov 2017, 'Effect of graphene nanosheets on electrochemical performance of $\mathrm{Li}_{4} \mathrm{Ti} 5 \mathrm{O} 12$ in lithium-ion capacitors', Ceramics International, vol. 43, no. 8, pp. 6554-6562. doi: 10.1016/j.ceramint.2017.02.083.

Lu, J, Chen, Z, Pan, F, Cui, Y \& Amine, K 2018, 'High-performance anode materials for rechargeable lithium-ion batteries', Electrochemical Energy Reviews. vol. 1, no. 1, pp. 35-53. doi: 10.1007/s41918-018-0001-4.

Park, JH, Kang, SW, Kwon, TS \& Park, HS 2018, 'Spraydrying assisted synthesis of a $\mathrm{Li}_{4} \mathrm{Ti} 5 \mathrm{O} 12 / \mathrm{C}$ composite for high rate performance lithium ion batteries', Ceramics International, vol. 44, no. 3, pp. 2683-269o. doi: 10.1016/j.ceramint.2017.10.217.

Qi, Y, Huang, Y, Jia, D, Bao, SJ \& Guo, ZP 2009, 'Preparation and characterization of novel spinel Li4Ti5O12-xBrx anode materials', Electrochimica Acta, vol. 54, no. 21, pp. 4772-4776. doi: 10.1016/j.electacta.2009.04.010.

Rho, YH \& Kanamura, K 2004, 'The advantages of LTO',
Journal of Solid State Chemistry, vol. 177, p. 2094.

Rutkowska, A, Konrad, S \& Sitarz, M 2017, 'Hierarchically structured lithium titanate for ultrafast charging in longlife high capacity batteries', pp. 1-7. doi: $10.1038 /$ ncomms15636.

Sandhya, CP, John, B \& Gouri, C 2014, 'Lithium titanate as anode material for lithium-ion cells: a review', Ionics, vol. 20, pp. 601-620. doi: 10.1007/s11581-014-1113-4.

Sohib, A, Priyono, S, Widayatno, WB, Subhan, A, Sari, SN, Wismogroho, AS, Hudaya, C \& Prihandoko, B 2020, 'Electrochemical performance of low concentration $\mathrm{Al}$ doped-lithium titanate anode synthesized via sol-gel for lithium ion capacitor applications', Journal of Energy Storage, 29, p. 101480. doi: 10.1016/j.est.2020.101480.

Özen, S, Şenay, V, Pat, S \& Korkmaz, Ş 2016, 'Optical, morphological properties and surface energy of the transparent Li4Ti5O12 (LTO) thin film as anode material for secondary type batteries', Journal of Physics D: Applied Physics, vol. 49, no. 10, p. 105303. doi: 10.1088/0022-3727/49/10/105303.

Subhan, A, Oemry, F, Khusna, SN \& Hastuti, E 2019, 'Effects of activated carbon treatment on $\mathrm{Li}_{4} \mathrm{Ti}_{5} \mathrm{O} 12$ anode material synthesis for lithium-ion batteries', Ionics, vol. 25, no. 3, pp. 1025-1034.

Sun, X, Radovanovicb, PV \& Cui, B 2014, 'Advances in spinel Li4Ti5O12 anode materials for lithium-ion batteries', New Journal of Chemistry, vol. 39, no. 1, pp. 38-63. doi: 10.1039/C4NJo139oE.

Tian, B, Xiang, H, Zhang, L \& Wang, H 2012, 'Effect of Nbdoping on electrochemical stability of Li4Ti5O12discharged to o V', Journal of Solid State Electrochemistry, vol. 16, no. 1, pp. 205-211. doi: 10.1007/s10008-011-1305-z.

Wang, F, Chen, H, Wu, Q, Mei, R, Huang, Y, Li, X \& Luo, Z 2017, 'Study on the mixed electrolyte of n,n-dimethylacetamide/sulfolane and its application in aprotic lithium-air batteries', ACS Omega, vol. 2, no. 1, pp. 236-242. doi: 10.1021/acsomega.6boo254.

Langhus, DL 2001, Analytical Electrochemistry, (Wang, Joseph), 2nd edn, New York: Wiley-VCH.

Wang, J, Zhao, H, Yang, Q, Zhang, T \& Wang, J 2013, 'Electrochemical characteristics of Li4-xCuxTi5O12 used as anode material for lithium-ion batteries', Ionics, vol. 19, no. 3, pp. 415-419. doi: 10.1007/s11581-012-0771-3.

Wang, Z, Wang, Z, Peng, W, Guo, H \& Li, X 2014, 'An improved solid-state reaction to synthesize $\mathrm{Zr}$-doped Li4Ti5O12 anode material and its application in 
LiMn2O4/Li4Ti5O12 full-cell', Ceramics International, vol. 40, no. 7, pp. 10053-10059. doi: 10.1016/j.ceramint.2014.04.011.

Yi, TF, Fang, ZK, Deng, L, Wang, L, Xie, Y, Zhu, YR, Yao, JH \& Dai, C 2015, 'Enhanced electrochemical performance of a novel Li4Ti5O12composite as anode material for lithiumion battery in a broad voltage window', Ceramics International, vol. 41, no. 2, pp. 2336-2341. doi: 10.1016/j.ceramint.2014.10.041.

Zhang, FF, Zhang, XB, Dong, YH \& Wang, LM 2012, 'Facile And effective synthesis of reduced graphene oxide encapsulated sulfur via oil/water system for high performance lithium sulfur cells', Journal of Materials Chemistry, vol. 22, no. 23, pp. 11452-11454. doi: 10.1039/c2jm16543k.

Zhang, Y, Wang, C \& Tang, X 2011, 'Cycling degradation of an automotive $\mathrm{LiFePO}_{4}$ lithium-ion battery', Journal of Power Sources, vol. 196, no. 3, pp. 1513-1520. doi: 10.1016/j.jpowsour.2010.08.070. 